\title{
Modern instruments of banking sector control and the effect they had since their implementation in Russian Federation
}

\author{
Karpova Darya P. \\ RUDN University \\ Moscow, Russian Federation \\ karpova_dp@rudn.university;
}

\author{
Kruglikova Elena V. \\ RUDN University \\ Moscow, Russian Federation \\ kruglikova_ev@rudn.university
}

\begin{abstract}
The main focus of this article is the analysis of various bank liquidity management instruments. Special attention is paid to the world banking regulation transformation under the influence of overall global instability.
\end{abstract}

Keywords- banking sector, liquidity management, Basel Capital Accor.

\section{INTRODUCTION}

The development of the banking system in conditions of economic instability requires effective functioning of the main financial institutions. A strategic approach to management in the banking sector makes it possible to maintain or improve the bank's position in the financial market, avoid risks, achieve specific goals. At the same time, liquidity is one of the key indicators of banking activity, characterizing the reliability and stability of banking institutions. In modern economic conditions, banking liquidity should be viewed as a multi-level system of categories that should reflect both the liquidity of the banking system and the liquidity of individual banks.

\section{FEATURES OF THE BANK'S LIQUIDITY MANAGEMENT IN RUSSIA}

The liquidity management of the banking sector is aimed at meeting the needs of credit institutions in funds on their correspondent accounts with the Bank of Russia to fulfill their mandatory reserve requirements and to implement their own and customer payments and settlements [1].

The modern instrument of the monetary policy of the Bank of Russia was formed as a universal mechanism, which can work both in the situation of a structural deficit and with a surplus of liquidity. However, its use is modified depending on the situation - the surplus or deficit - in the banking sector. Structural deficits represent a steady need for the banking sector in attracting liquidity from transactions with the Bank of Russia. Structural surplus is a stable need for placing free funds of banks with the help of Bank of Russia operations. Liquidity in the banking sector is unevenly distributed between the individual banks. Banks which failed to provide a balance of supply and demand through operations in the financial market are turning to the Bank of Russia's ongoing operations. The Bank of Russia conducts operations every day both for providing and absorbing liquidity. Therefore, the level of structural deficit and surplus is defined as the difference between the debt of credit institutions for refinancing operations with the Bank of Russia and the Bank of Russia's indebtedness to them for liquidity absorption operations. The current state of the Russian banking sector is characterized by a surplus of liquidity, the transition which occurred in the first half of 2016. In December 2017, the structural surplus of liquidity in the banking sector in Russia has increased significantly. At the same time, the main inflow of liquidity into the banking sector was associated with financing the budget deficit at the expense of sovereign funds. [2]

In 2018, the structural liquidity surplus in the Russian banking sector is expected to grow. As the banks adapt to the increased liquidity surplus and decrease in turnover in their operations, it is likely that the volume of bank applications will be increased at the Bank of Russia's deposit auctions, as well as the growth of their investments in CBR coupon bonds. The forecast of a structural liquidity surplus at the end of 2018 is 3.1-3.5 trillion rubles. The main inflow of funds to banks is expected as a result of financing the budget deficit at the expense of the National Welfare Fund [3] 
TABLE I $\quad$ STRUCTURAL LIQUIDITY FORECAST

\begin{tabular}{|c|c|c|}
\hline \multirow{2}{*}{ Liquidity indicator } & \multicolumn{2}{|c|}{$\begin{array}{l}\text { Level of liquidity, trillion } \\
\text { rubles }\end{array}$} \\
\hline & 2017 & $\begin{array}{c}2018 \\
\text { forecast }\end{array}$ \\
\hline $\begin{array}{l}\text { 1. Liquidity formation factors } \\
\text { (offer) }\end{array}$ & 3,3 & {$[1,0 ; 1,3]$} \\
\hline $\begin{array}{l}\text { - changes in balances on the } \\
\text { accounts of the extended } \\
\text { government with the Bank of } \\
\text { Russia and other transactions }\end{array}$ & 3,4 & {$[1,6 ; 1,8]$} \\
\hline - change of cash in circulation & $-0,6$ & {$[-0,6 ;-0,5]$} \\
\hline $\begin{array}{l}\text { - intervention of the Bank of } \\
\text { Russia in the domestic foreign } \\
\text { exchange market and operations } \\
\text { for the purchase of monetary } \\
\text { gold }\end{array}$ & 0,5 & - \\
\hline $\begin{array}{l}\text { regulation of mandatory } \\
\text { reserves of credit institutions } \\
\text { with the Bank of Russia }\end{array}$ & 0,0 & 0,0 \\
\hline $\begin{array}{l}\text { 2. Change in free bank reserves } \\
\text { (correspondent accounts) } \\
\text { (demand) }\end{array}$ & 0,1 & {$[0,2 ; 0,3]$} \\
\hline $\begin{array}{l}\text { 3. Changes in the requirements } \\
\text { of credit institutions for } \\
\text { deposits with the Bank of } \\
\text { Russia and the CBR coupon } \\
\text { bonds }\end{array}$ & 1,9 & {$[0,5 ; 1,1]$} \\
\hline $\begin{array}{l}\text { 4. Changes in the indebtedness } \\
\text { for refinancing operations of the } \\
\text { Bank of Russia }(4=2+3-1)\end{array}$ & $-1,2$ & {$[-0,1 ; 0,1]$} \\
\hline $\begin{array}{l}\text { Structural deficit (+)/ surplus (- } \\
\text { ) liquidity (at the end of the } \\
\text { period) }\end{array}$ & $-2,6$ & {$[-3,5 ;-3,1]$} \\
\hline
\end{tabular}

Governments of many countries tie the stability of their respective banking systems with the formation of various new unified institutes and instruments of regulation and supervision over financial and banking sectors, both on national and international levels - so called mega-regulators.

These institutes have to control operations of all participants on financial market and to use new methods of bank supervision, that were developed and approved on 12.09.2010 by the Basel bank regulation committee which have been shown in the "International Convergence of Capital Measurement and Capital Standards: Revised Framework » (Basel II) and in «A global regulatory framework for more resilient banks and banking systems») (Basel III). The main goal of these new approaches towards banking sector regulation is the significant increase of its resistance to the external influences and shocks.

\section{BASEL III: WHAT IS NEW IN BANKING SECTOR REGULATION?}

A new banking regulation paradigm, which is being realized by the Central Bank of Russia based on the Basel III, is directed towards reinforcing of banking sector stability, growth of new defense mechanisms and barriers of each credit organization from external shocks and influences, and lowering the risk factors of their operation, stimulation of banking sector consolidation and removal of procyclicality. It is worth noting that thanks to the actions undertaken by the
Central Bank of Russia, the shocks that came with the financial crisis in the years 2007-2009 were neutralized in a timely and orderly fashion.

However, the integration of new approaches and standards in banking sector regulations generates new risks for credit organizations.

First of all, the new paradigm of international banking regulation (Basel III) should be providing solutions for the regulative gaps of previous years. Mainly through effective regulation of largest or most vital banks, which means those, that are "immune" against bankruptcy and whose loses from their activities and operations are being "nationalized", since the state of these banks directly influences both national economies and global finances. These banks can afford to fulfill the growing capital requirement and financial leverage standards which have been implemented by the Central Bank of Russia by statement № 172-E issued on 30.07.2013.

The raise of standards for capital sufficiency, liquidity and financial leverages was not welcomed by Russian banks. In 2016 about 110 banks were closed, 97 had their licenses revoked. Central Bank officials of Russia think that most of these were problematic banks and banks that had poor quality accountability. At this moment under the riskiest category of banks there are fall banks listed within the list of top 100 actives ratings. A fact by itself speaks about the tensions that is present within the Russian banking sector.

At present, banks from the first hundred rating of assets fall into the risk group. This shows the tensions in the banking sector, including the result of the introduction of Basel III.

This caused the situation where the banking system started going through "domino effect". A very good example of this is the situation between banks «Tatfondbank» [4] and «Peresvet» [5]. After temporal administration were forced upon «Peresvet» bank, «Tatfondbank» started to have trouble with its liquidity since it held around 4-5 billion rub of «Peresvet» obligations which were around $18 \%$ of its capital. In fact, this was one of the reasons why, along with «Tatfondbank», the «Intechbank» lost its license. Further other reasons added up such as panic of investors which led to another bank losing its license. The mentioned bank was «Ankorbank».

This "domino effect" was and still is caused by the fact that the government supports large banks while the real financial strain of today's economical processes and operations is held on the shoulders of the "second class" banks, the main creditors in real sector. However, the raised standards for the minimal amount of sufficient capital that are supposed to increase the stability and narrow down the time windows during which potential future financial crisis would be affecting things, are forcing banks to be more careful and to put more thought into the formation of their capital and financial actives and reserves. Central Bank of Russia is slowly stopping, being an independent regulator, and prefers to help the largest banks of its country. According to the Central Bank of Russia, the bank stability and reliability rating was at the moment of its issue as follows [6]. 
TABLE II. THE BANK STABILITY AND RELIABILITY RATING

\begin{tabular}{|l|l|l|}
\hline \multirow{2}{*}{ Rating } & \multicolumn{2}{|c|}{ Top 10 banks } \\
\cline { 2 - 3 } & \multicolumn{1}{|c|}{ Bankital } \\
\hline 2 & Sberbank & 3694397,9 million rub. \\
\hline 3 & Bank VTB & 1061710,1 million rub. \\
\hline 4 & Bank Gazprombank & 705373,9 million rub. \\
\hline 5 & Russian Agricultural Bank & 420589,6 million rub. \\
\hline 6 & VTB 24 Bank & 371634,5 million rub \\
\hline 7 & Bank «Alfa-bank» & 335021,5 million rub \\
\hline 8 & Credit Bank of Moscow & 252196,2 million rub \\
\hline 9 & Otkritie Bank & 222185,6 million rub \\
\hline 10 & UniCredit Bank & 200874,7 million rub \\
\hline
\end{tabular}

In this list of the biggest and best, 10 banks are holding roughly $60 \%$ of total actives of the whole Russian banking sphere.

In the assets of the Russian banking sector, a high proportion is held by banks with a state share, which is provided with substantial support. This problem is linked to the problem of large banks. In the last decade, there has been a trend towards an increase in the share of state-owned banks in the banking sector's assets. If before the economic crisis of 1998 the share of assets of state and quasi-public banks was about $31 \%$ of the total assets of banks, by 2009 this share had grown to 54\%, [7], and by 2010 it was $42.6 \%$. By the end of 2011, the total weight of seven financial institutions dominated by state or state-owned companies amounted to $27.7 \%$ of the banking sector assets, and together with the Savings Bank of Russia - 54.6\%. Data at the beginning of 2018 are reflected in the table [6].

TABLE III. TYPES OF CREDIT INSTITUTIONS GROUPS

\begin{tabular}{|l|l|c|c|}
\hline \multirow{2}{*}{$\begin{array}{c}\text { Groups of credit } \\
\text { institutions }\end{array}$} & \multicolumn{3}{|c|}{$\begin{array}{c}\text { Indicators of individual groups of credit } \\
\text { institutions }\end{array}$} \\
\cline { 2 - 4 } & $\begin{array}{c}\text { Number of } \\
\text { credit } \\
\text { institutions }\end{array}$ & $\begin{array}{c}\text { Share in } \\
\text { total assets } \\
\text { of the } \\
\text { banking } \\
\text { sector, } \%\end{array}$ & $\begin{array}{c}\text { Share in } \\
\text { total } \\
\text { capital } \text { of } \\
\text { the } \\
\text { banking } \\
\text { sector, \% }\end{array}$ \\
\hline $\begin{array}{l}\text { Banks controlled } \\
\text { by the state }\end{array}$ & 20 & 59 & 64,2 \\
\hline Total Banks & 561 & 100 & 100 \\
\hline
\end{tabular}

However, nearly all of the banks of this "Ten" are held afloat only thanks to funding from sovereign wealth fund of Russia, namely banks like VTB, «VTB24», «Gazprombank», «Alfa-bank», FC «Otkritie Bank» and «Russian Agricultural Bank». It is also worth noting that at this point in time Central Bank of Russia, money reserves have significantly dwindled and so far it seems that the central bank doesn't want to spend money on any other banks except the one's in the list of "Ten".

Nevertheless, in 2017, in relation to large banks (the first ten), a new mechanism of sanitation was invented. If until 2017 reorganization of credit institutions was based on a "credit facility", in which troubled banks or investors making sanitation, received long-term loans at below-market rates from the State Corporation "Deposit Insurance Agency", receiving in turn loans from the CBRF. In 2017, the CBR is conducting the reorganization through the Fund for the Consolidation of the Banking Sector. The Bank of Russia at the expense of the Fund purchases and sells shares in the authorized capital of the sanitized bank, property and claims to such bank, lends, places deposits to maintain liquidity, issues guarantees. Fund consolidation of the banking sector is formed at the expense of the CBR and; therefore, the CBR becomes the main shareholder of a private bank for the period of rehabilitation, which, in fact, means nationalization.

The ultimate goal of managing banks that have undergone the recapitalization procedure in accordance with the bill is their sale. The Bank of Russia expects to sell stakes in the authorized capital of credit institutions that are subjected to measures preventing bankruptcies. Thus, the CBR gets the opportunity to participate in the redistribution of property in the sphere of large banking business. In addition, the authors of the draft law believe that the sources and mechanisms for financing reorganization established by the draft law will allow the issuance of a resource of the Bank of Russia that is emissive in its nature in the least amount.

Here is another question about the availability of investors who can buy such bank. Due to the huge scale and potential high cost, only the largest financial holdings and state-owned banks can be interested in purchasing. At the same time, banks with state participation are already experiencing an influx of customers due to the unstable situation in the banking sector and are unlikely to be interested in such expensive purchases. The acquisition of these banks may theoretically be interesting for large foreign investors, but not in the current phase of the macroeconomic and sanctions policies.

A pilot project in this area was the rehabilitation of the largest private bank Otkrytie with assets of 2.45 trillion rubles. During the reorganization, the bank itself continues to operate as usual. In the regular mode, all organizations that are members of the bank group (Rosgosstrakh, Trust Bank, Rosgosstrakh Bank, APF Lukoil-guarantor, NPF Electricity, NPF RGS, Broker Opening, as well as "Point" and Roketbank). According to the Central Bank of Russia, the reorganization of Bank Otkrytie will require financial expenditures of 250-400 billion rubles.

\section{THE BAIL-IN MECHANISM AS AN ALTERNATIVE TO ANTI-CRISIS MANAGEMENT OF BANKS}

An alternative to the anti-crisis management of a credit institution could be a comprehensive mechanism for the recovery of systemically important credit institutions, combining restructuring agreements with bank creditors and Bail in procedures, as well as the possibility of partial 
reorganization without terminating the work of the credit institution.

In the European Union, the bail-in mechanism has been in effect since January 1, 2016. According to the Directive on Bank Restructuring and Bankruptcy, approved in April 2014, the burden of saving a credit institution should be transferred to shareholders and creditors of financial institutions. According to the procedure stipulated by the document, liabilities to shareholders (capital) are completely written off first, then liabilities to holders of bonds are converted into capital and finally large deposits amounting to more than $€$ 100 thousand. Deposits for a smaller amount should be guaranteed by the state and do not participate in the procedure. Financial authorities can be connected to the procedure for reorganization only after creditors and shareholders participate in it. The latter have a chance to return their funds or reduce losses through the receipt of dividends or the sale of shares in the future. This mechanism, in the opinion of the European Commission, provides for a minimum burden on taxpayers. The credit organization remains in the market and does not violate its competitive structure.

For example, in the same way, banks in Cyprus were rehabilitated in 2013 (in the Bank of Cyprus, $47.5 \%$ of deposits over 100 thousand euros were exchanged for shares) [8]. In this case, the bank's financial recovery was due to the conversion of claims of the largest creditors, and not at the expense of taxpayers. 21 thousand customers of the bank, whose deposits exceeded $€ 100$ thousand, became owners of $81.4 \%$ of the bank's shares, after $47.5 \%$ of their uninsured savings were converted into share capital at a rate of $€ 1$ per share.

The main advantage of this method is that the credit institution remains on the market and continues to operate. The application of this mechanism will not only reduce the amount of taxpayers' money (they join the credit organization only after the exhaustion of the possibilities of its key creditors) directed to its improvement, but also to avoid excessive monopolization in the banking sector.

This means that most of the attention of the Central Bank of Russia is focused on banks that have so called "bankruptcy immunity".

Firstly, this mega-regulator policy is understandable and pretty simple. Collapse of a single bank from the top 10 will inevitably lead to the collapse of the whole national banking system. Supported by the Russian government, banks will remain as the most reliable ones until the national reserves run dry. Along with other factors, this support of ultimately ineffective large banks leads towards money reserves exhaustion and creates an environment where the banks that have no access to state held funds and resources and cannot use the option to nationalize the results of their ineffective activities have much worse position.

Secondly, the banking sector has a significant multiplication effect. Optimization of the banking sector left around 20 thousand people unemployed and these people cannot find any work in the financial sector, since the amount of credit organization keeps declining. Reduction of the bank institutions amount on the market leads to lower competition.

Resistance of credit organizations towards negative impacts of today's financial relations is nowadays lowered by 2 main areas. Firstly these are socially-economic problems that become a cause for increased risk of bank liquidity loss [9]. Furthermore, conditions are being created during which credit organizations cannot fulfill their promises and obligations before their clients and as a consequence, their financial sustainability is being compromised. More than that, problems stemming from socially-economic development are making an impact on the quality of available bank actives and services, lead to a rise in credit, interest and fund risks, which in the end leads to a decline of the profitability and costeffectiveness of their operations. Impossibility of fulfillment of mega-regulators demands in accord with Basel standards has become a justification for action which can lead to ultimate license revoke and liquidation of a bank. And under these circumstances, a never ending cycle begins that is often very hard to break and fix.

Thirdly, there still are unregulated segments of the financial sector, which are affecting the financial stability as a whole. "Shadow banks" are luring clients in with the promise of easy bank loans with very low interest rates. Lack of financial education causes clients to go to these banks and use the products of these micro-financial organizations. In order to keep themselves afloat and keep their products available, they have to resort to high risk operations. This policy increases the risks of the financial sector as a whole because ultimately the funding sources are the same for both shadow and real sectors. Credit organizations are interconnected and mutually dependent of each other, which is not being taken into consideration by the mega-regulator and as a result leads to increased risks and lowers the overall effect of the whole regulation reform.

\section{DISCUSSION}

Close attention towards system-founding banks and concentration of financial efforts in order to support them might lead to a situation where financial sector development vector is determined by speculations of investors, which may again lead to irrational decisions. In other words, with this course of development there is a danger of serious disruption of market mechanisms in the financial sector and subsequently affect the state of economy as a whole.

At the same time, domination of the banking sector in the Russian financial system (many experts agree that its actives share in the sector of finances is as large as $85-90 \%$ of all financial actives) and banking sector influence on overall dynamics of Russian financial market is one of the biggest threats and factors that are causing the growth of risks and increased stress on the banking sector in the context of economic instability. (for comparison in the USA the banking sector share of all financial actives is only $54 \%$, in China $52,2 \%$, in Brazil - 59,4\% [10]).

Peculiarity and low adaptability of Russian credit institutes towards external shocks, diversity of their actives, and significant vulnerability of their operational models greatly 
lowers the effect of Basel III standards, whose main goal is to ensure predictability and stability of Russian banking sector, its ability to provide real sector with reliable financial resources.

Currently, as a result of sanctions, Russian credit organizations don't have access to high-liquidity and attractive financial markets, which significantly increases the risks.

Thus, because of the Basel standards that were meant to improve the oversight over the banking sector in order to protect it from various risks, we are having more risks. Therefore, high levels of risks in the banking sector in the context of long term uncertainty will be the main determining factor which will direct the course of the banking sector in its search of ways how to survive, persist and find new instruments which would be necessary for successful operation under Basel III directives

However the major plus of this standard is the fact that, as the author of the "Global reform of financial regulation: first results and new challenges»[11], realization of the Basel standards doesn't require much if any international cooperation between countries and is encouraging national implementation of these standards through passing of respective necessary laws and acts.

Certainly, introduction of the new international banking sectors regulation standards (specifically Basel I-III), is necessary. However, nobody can give any guarantees that during and after the transition period towards new approaches to supervision and regulation of banking systems the mentioned banking systems will be able to independently resolve any encountered problems and will raise its effectiveness. These standards are created by international organizations, based on great amount of data supplied by various other organizations. However these organizations do not make test any of these new standards in a closed research environment and as such, there is no information how each new version of international standards will behave in the system. Every such standard is just an attempt to optimize regulations, restrictions, methods of evaluation, risk analysis in the economics as a whole and banking sectors in particular.

\section{References}

[1] "Osnovnye napravleniya edinoj gosudarstvennoj denezhno-kreditnoj politiki na 2016 god i period 2017 i 2018 godov", URL: http://www.cbr.ru/publ/ondkp/on_2016(2017-2018).pdf

[2] 'Central'nyj bank Rossii. Likvidnost' bankovskogo sektora i finansovye rynki”, URL: http://nfo2017.ru/ru/upload/LB_2017-22.pdf

[3] "Ministerstvo finansov Rossijskoj Federacii. Osnovnye napravleniya byudzhetnoj, nalogovoj i tamozhenno-tarifnoj politiki na 2018 god i planovyj period 2019 i 2020 godov", URL: https://www.minfin.ru/ru/document/?id_4=119695

[4] Handbook of the Central Bank on to credit institutions, JSC Tatfondbank URL://http://cbr.ru/credit/coinfo.asp?id=920000022

[5] "The directory of the Bank of Russia to credit institutions joint-stock commercial Bank for assistance of charity and spiritual development of Fatherland Peresvet", URL: http://cbr.ru/credit/coinfo.asp?id=450000272.

[6] "The reference to credit institution, the Central Bank of the Russian Federation", URL://www.cbr.ru/main.asp.

[7] "Structural modernization of Russia's financial system. Analytical report", p. 81. http://uisrussia.msu.ru/docs/nov/insor/Str_modern.pdf

[8] A. Tabah, "Owners unwillingly: why do we need a bail-in mechanism", URL: http://www.forbes.ru/mneniya-column/konkurentsiya/311655 sobstvenniki-ponevole-zachem-nuzhen-mekhanizm-bail

[9] Yu.A. Rovenskiy, N.N. Natocheeva, V.M. Poletaeva, "Socio-economic problems that reduce the financial stability of Russian credit organization sector", in Money and credit, no. 2, pp. 69-74, 2017

[10] E.P. Dzhagityan, "Basel III in Russia: synchronization of regulatory reform on the background of systemic risk", in Money and credit, no. 7 pp.47-58, 2016

[11] L.S. Khudyakova, V.K. Kulakov, E.A. Sidorova, "Global reform of financial regulation: first results and new challenges", Money and credit, no. 5 , pp. 28-38. 2016 